\title{
Age and growth of pompano, Trachinotus ovatus, from the Strait of Messina (central Mediterranean Sea)
}

\author{
Danilo Malara ${ }^{1}$, Francesco Longo ${ }^{2}$, Luca Pagano 2, Maria Giulia Stipa ${ }^{2}$, Teresa Romeo ${ }^{3,4}$, \\ Franco Andaloro ${ }^{5}$, Silvestro Greco ${ }^{1}$, Pietro Battaglia ${ }^{2}$ \\ ${ }^{1}$ Stazione Zoologica Anton Dohrn, Calabria Marine Centre, CRIMAC, Integrated Marine Ecology Department, \\ C. da Torre Spaccata, 87071 Amendolara (CS), Italy. \\ (DM) (Corresponding author) E-mail: danilo.malara@ szn.it. ORCID iD: https://orcid.org/0000-0002-7182-1848 \\ (SG) E-mail: silvestro.greco@szn.it. ORCID iD: https://orcid.org/0000-0002-2137-5675 \\ ${ }^{2}$ Stazione Zoologica Anton Dohrn, Sicily Marine Centre, Integrated Marine Ecology Department, \\ Villa Pace-Contrada Porticatello n. 29, 98167 Messina, Italy. \\ (FL): E-mail: francesco.longo@szn.it. ORCID iD: https://orcid.org/0000-0001-5950-981 \\ (LP) E-mail: luca.pagano@szn.it. ORCID iD: https://orcid.org/0000-0002-4319-0014 \\ (MGS) E-mail: mariagiulia.stipa @ szn.it. ORCID iD: https://orcid.org/0000-0001-6674-879X \\ (PB) E-mail: pietro.battaglia@ szn.it. ORCID iD: https://orcid.org/0000-0003-1822-7775 \\ ${ }^{3}$ Stazione Zoologica Anton Dohrn, Sicily Marine Centre, Integrated Marine Ecology Department, Via dei Mille 46, \\ 98057 Milazzo (ME), Italy. \\ (TR) E-mail: teresa.romeo@szn.it. ORCID iD: https://orcid.org/0000-0001-8515-1964 \\ ${ }^{4}$ ISPRA, National Institute for Protection and Environmental Research, Via dei Mille 46, 98057 Milazzo (ME), Italy. \\ ${ }_{5}^{5}$ Stazione Zoologica Anton Dohrn, Sicily Marine Centre, Integrated Marine Ecology Department, Lungomare Cristoforo \\ Colombo (ex Complesso Roosvelt), Località Addaura n. 4521, 90100 Palermo, Italy. \\ (FA) E-mail: franco.andaloro@ szn.it. ORCID iD: https://orcid.org/0000-0001-6245-9819
}

\begin{abstract}
Summary: This is the first paper to provide detailed information on the age and growth of Trachinotus ovatus. The size of the 244 individuals collected in the Strait of Messina ranged from 2.7 to $30.4 \mathrm{~cm}$ in fork length $\left(L_{\mathrm{F}}\right)$ and 0.31 to $508.6 \mathrm{~g}$ in body mass $(M)$. The relationship between these parameters $\left(M-L_{\mathrm{F}}\right)$ was investigated and showed a good fit. Age estimation based on vertebrae and otoliths yielded similar results, suggesting a maximum age of five years. However, the precision and accuracy tests, such as percentage of agreement (PA), mean coefficient of variation (ACV) and average percent error (APE) indicated that the otolith readings $(97.83 \% \mathrm{PA}, 0.54 \% \mathrm{ACV}$ and $0.38 \% \mathrm{APE}$ ) were more reliable for age estimation than vertebrae readings $(82.17 \% \mathrm{PA}, 5.33 \% \mathrm{ACV}$ and $3.77 \% \mathrm{APE})$. The multi-model inference approach allowed us to compare different non-linear growth models. The von Bertalanffy model $\left(L_{\infty}=29.139, k=0.496\right.$ and $\left.t_{0}=-0.347\right)$ fitted the length-at-age data best. This species has a relatively rapid growth and an estimated longevity of five to seven years. This information could be used for management and first stock assessment studies on T. ovatus in the Mediterranean Sea.
\end{abstract}

Keywords: otolith; vertebrae; age determination; growth models; length-weight relationship; Carangidae.

Edad y crecimiento del pámpano, Trachinotus ovatus, del Estrecho de Messina (Mediterráneo central)

Resumen: Este es el primer artículo que proporciona información detallada sobre la edad y el crecimiento de Trachinotus ovatus. El tamaño de los 244 individuos recolectados en el Estrecho de Messina osciló entre 2.7 y $30.4 \mathrm{~cm}$ de longitud a la horquilla $\left(L_{\mathrm{F}}\right)$ y 0.31 a $508.6 \mathrm{~g}$ de masa corporal $(M)$. Se investigó la relación entre estos parámetros $\left(M-L_{\mathrm{F}}\right)$ y mostró un buen ajuste. La estimación de la edad basada en vértebras y otolitos arrojó resultados similares, lo que sugiere una edad máxima de cinco años. Sin embargo, las pruebas de precisión y exactitud, como el porcentaje de concordancia (PA), el coeficiente medio de variación (ACV) y el porcentaje de error medio (APE), indicaron que las lecturas del otolito (97.83\% PA, 0.54\% ACV y $0.38 \%$ APE) fueron más confiables para la estimación de la edad que las lecturas de vértebras $(82.17 \%$ PA, 5.33\% ACV y $3.77 \%$ APE). El enfoque de inferencia de modelos múltiples nos permitió comparar diferentes modelos de crecimiento no lineal. El modelo de von Bertalanffy $\left(L_{\infty}=29.139, k=0.496\right.$ and $\left.t_{0}=-0.347\right)$ se ajusta mejor a los datos de talla por edad. Esta especie tiene un crecimiento relativamente rápido y una longevidad estimada de cinco a siete años. Esta información podría utilizarse para la ordenación y los primeros estudios de evaluación de poblaciones de T. ovatus en el mar Mediterráneo.

Palabras clave: otolito; vértebras; determinación de la edad; modelos de crecimiento; relación longitud-peso; Carangidae.

Citation/Como citar este artículo: Malara D., Longo F., Pagano L., Stipa M.G., Romeo T., Andaloro F., Greco S., Battaglia P. 2021. Age and growth of pompano, Trachinotus ovatus, from the Strait of Messina (central Mediterranean Sea). Sci. Mar. 85(3): 175-185. https://doi.org/10.3989/scimar.05167.016

Editor: J. Lloret.

Received: February 3, 2021. Accepted: April 28, 2021. Published: August 13, 2021.

Copyright: (C) 2021 CSIC. This is an open-access article distributed under the terms of the Creative Commons Attribution 4.0 International (CC BY 4.0) License. 


\section{INTRODUCTION}

Trachinotus ovatus (Linnaeus, 1758), or pompano, is a pelagic school-forming species of fish (Smith-Vaniz 1986) belonging to the Carangidae family. It is distributed in the Mediterranean Sea and the eastern Atlantic Ocean, mainly in tropical and subtropical waters (Smith-Vaniz 1986). This species prefers clear waters (Smith-Vaniz 1986) with a sand/mud bottom composition (Reiner 1996) and is thermophilic (Bianchi et al. 2014). Owing to the Mediterranean "meridionalization" (Andaloro and Rinaldi 1998), its Mediterranean distribution is now extending to the northeast (Azzurro 2008, Azzurro et al. 2011). The rising water temperature is part of the climate change effect (Nykjaer 2009, Shaltout and Omstedt 2014), a serious issue affecting the Mediterranean marine biota and ecosystems (Andaloro and Rinaldi 1998, Lejeusne et al. 2010, Givan et al. 2018). In the last few years, the warming has caused fluctuations in the abundance and distribution of endemic species, as well as the settlement of some alien species (Lasram et al. 2010, Albouy et al. 2013, Givan et al. 2018). The higher water temperature could induce reproductive and recruitment failure in cold thermal affinity species, while benefiting the reproductive cycle of warm thermal affinity species (Munday et al. 2008, Pankhurst and Munday 2011, Pranovi et al. 2016), such as pompano. Indeed, the pompano is becoming an important fish resource for local artisanal fisheries (Battaglia et al. 2017a), as well as an alternative to former common target species, because its catches have increased alongside the decrease in other common commercial fish, such as Scombridae and Clupeidae (Azzurro et al. 2011). This species is also considered an interesting candidate for aquaculture because of its fast growth and high flesh quality (Tan et al. 2016), as demonstrated by different experimental captivity rearing attempts (e.g. Tutman et al. 2004, Tan et al. 2016, Liu et al. 2019). The recent encouraging results notwithstanding (Liu et al. 2020), the main obstacle for the use of T. ovatus in Mediterranean aquaculture is the high cost of growing T. ovatus to market size (Tutman et al. 2004). Additional challenges are slow growth and signs of deformity when cultured outside its optimum temperature $\left(26^{\circ} \mathrm{C}-29^{\circ} \mathrm{C}\right.$; Yang et al. 2016) or salinity range (15\%o-25\%o; Liu et al. 2019) and infections, mainly caused by Vibrio bacteria (Tan et al. 2017).

Little information exists on the biology and ecology of this species in Mediterranean waters, and few data are available on trophic ecology, reproduction and life history. The existing studies on the feeding habits of $T$. ovatus report that adults feed mainly on pelagic fish and crustaceans (Battaglia et al. 2016a), while juveniles prefer crustaceans, benthic foraminifera and insects (Batistić et al. 2005). In terms of reproduction, Tortonese (1975) suggested that this species usually spawns in the summer. Similar conclusions were also reached by Chervinski and Zorn (1977) after they observed juveniles near Israeli coast in August.

To our knowledge, very few studies have been conducted on the life history of T. ovatus. Mourad (1999) investigated the relationship between age and otolith weight of a pompano population from Egyptian waters. Length-weight relationships were recorded for the northeastern Atlantic populations of T. ovatus (Morato et al. 2001, Santos et al. 2002, Oliveira et al. 2015) and estimated for individuals caught in the eastern (Abdallah 2002, Moutopoulos et al. 2013, Altin et al. 2015) and northwestern Mediterranean Sea (Morey et al. 2003, Villegas-Hernández et al. 2016).

Given the increasing importance of $T$. ovatus as a resource in Mediterranean fisheries (e.g. Azzurro et al. 2011, Battaglia et al. 2017a) and its potential use in aquaculture (e.g. Tutman et al. 2004, Tan et al. 2016, Liu et al. 2019), the main aim of this paper is to improve knowledge of the life history of this species and provide baseline data that would be useful for aquaculture and fishery management. Age and growth data are essential for understanding stock health. In this paper, for the first time, both otolith and vertebrae are used to investigate the age structure of a population of T. ovatus. Moreover, a multi-model inference approach was used, comparing various growth models (von Bertalanffy, Gompertz and logistic models) built on length-at-age data in order to assess which one better fits the T. ovatus population in the study area.

\section{MATERIALS AND METHODS}

\section{Data collection}

This research paper did not involve animal experimentation or treatment of or harm to live animals. No permits were required for animal collections, because all fish samples were already dead at the time of sampling. Animals under the size of $9 \mathrm{~cm}$ (fork length) were found stranded on the shore, while larger individuals were bought at landings of artisanal fishing boats. Stranding events in the Strait of Messina depend on a combination of wind direction, lunar phases and tidal currents, as well as upwelling events, which are common in this area and affect epipelagic and mesopelagic fauna (Battaglia et al. 2017b). We collected the stranded T. ovatus specimens before sunrise to avoid weight loss due to dehydration (according to the methodology provided by Battaglia et al. 2017b), and only undamaged individuals were selected.

A total of $244 T$. ovatus were collected between 2012 and 2014 in the area of the Strait of Messina in the central Mediterranean Sea (Fig. 1); of these, 119 were caught with trolling lines and 125 were found stranded on the shore. All fish were weighed to the nearest 0.01 $\mathrm{g}$ (total mass, $M$ ), and morphometric measurements were recorded to the nearest $0.1 \mathrm{~cm}$ (fork length $=L_{\mathrm{f}}$ ). Subsequently, sagittal otoliths were removed from the vestibular apparatus, cleaned and stored dry. The fish carcass was preserved frozen in order to extract vertebrae for age determination. It was possible to obtain otoliths and vertebrae from 230 individuals.

\section{Age determination}

About 60 minutes before the readings, the entire left otoliths from each pair (or the right one when left oto- 


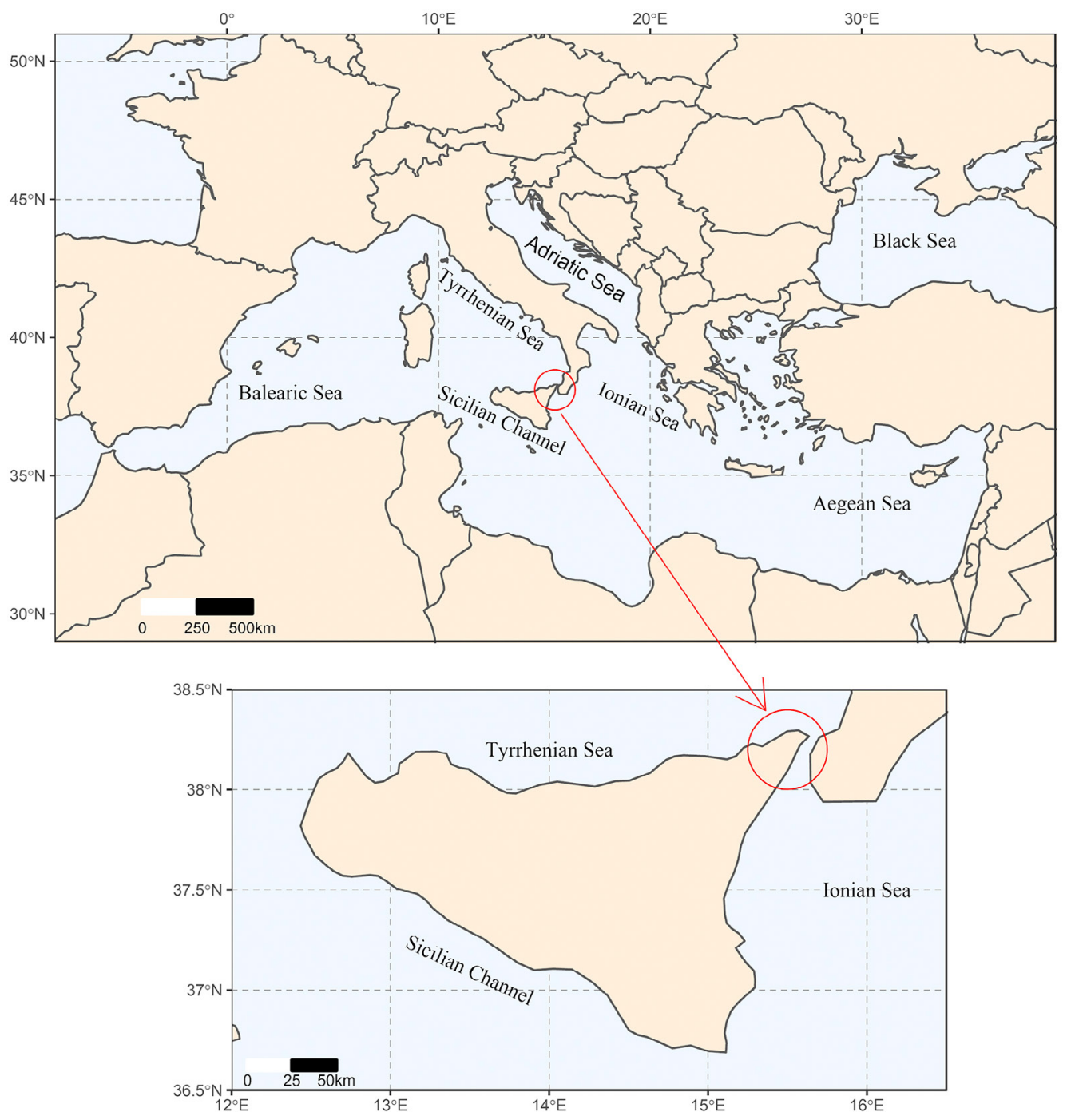

Fig. 1. - Trachinotus ovatus collection areas in the Strait of Messina, central Mediterranean Sea.

lith was found damaged) were soaked in a solution of ethanol $(70 \%)$ and glycerine (1:1) to make the growth increments clearer. The concave side of the otolith, fully covered by the ethanol-glycerine solution, was observed using a stereomicroscope (Carl Zeiss, model Discovery V.8, Germany). The samples were illuminated using reflected light over a dark background. Images were acquired using an Axiocam 208 colour camera (ZEISS), and post-production was performed using ZEN 3.1 software blue edition (ZEISS) to emphasize the annual growth increments. Annual growth increments (one translucent ring plus one opaque ring) were detected from the core to the rostrum, but their continuity was checked around the otolith edges wherever possible (Fig. 2A) in order to avoid considering false rings (Battaglia et al. 2016b). It is known that the difficulties associated with the observation of the clear opaque or translucent rings due to the presence of false rings may lead to an under- or over-estimation of yearly deposited increments (Campana 2001, Panfili et al. 2002, Carbonara and Follesa 2019).
Vertebrae preparation and colouration were done following the methodology reported by Castriota et al. (2014). The vertebrae were cleaned from fleshy parts by immersion in boiling water. After this, the neural and haemal spines were cut off. The vertebral centrum was cleaned and stained with alizarin red in a solution of $\mathrm{NaOH}$ and glycerine for 4-8 hours. After this period, the centrum was washed and dried in preparation for counting the growth increments under the stereomicroscope under reflected light (Fig. 2B). Readings were performed on a set of at least four vertebrae per individual.

Following previous studies (Battaglia et al. 2010, Consoli et al. 2010, Castriota et al. 2014), annual rings (one opaque plus one translucent ring in the otolith; one dark plus one light band in the vertebra) were counted independently for both otoliths and vertebrae by two operators in order to limit interpretation mistakes. When the readings were discordant, a second observation was carried out, and if this last reading still provided inconsistent results, the sample was rejected 

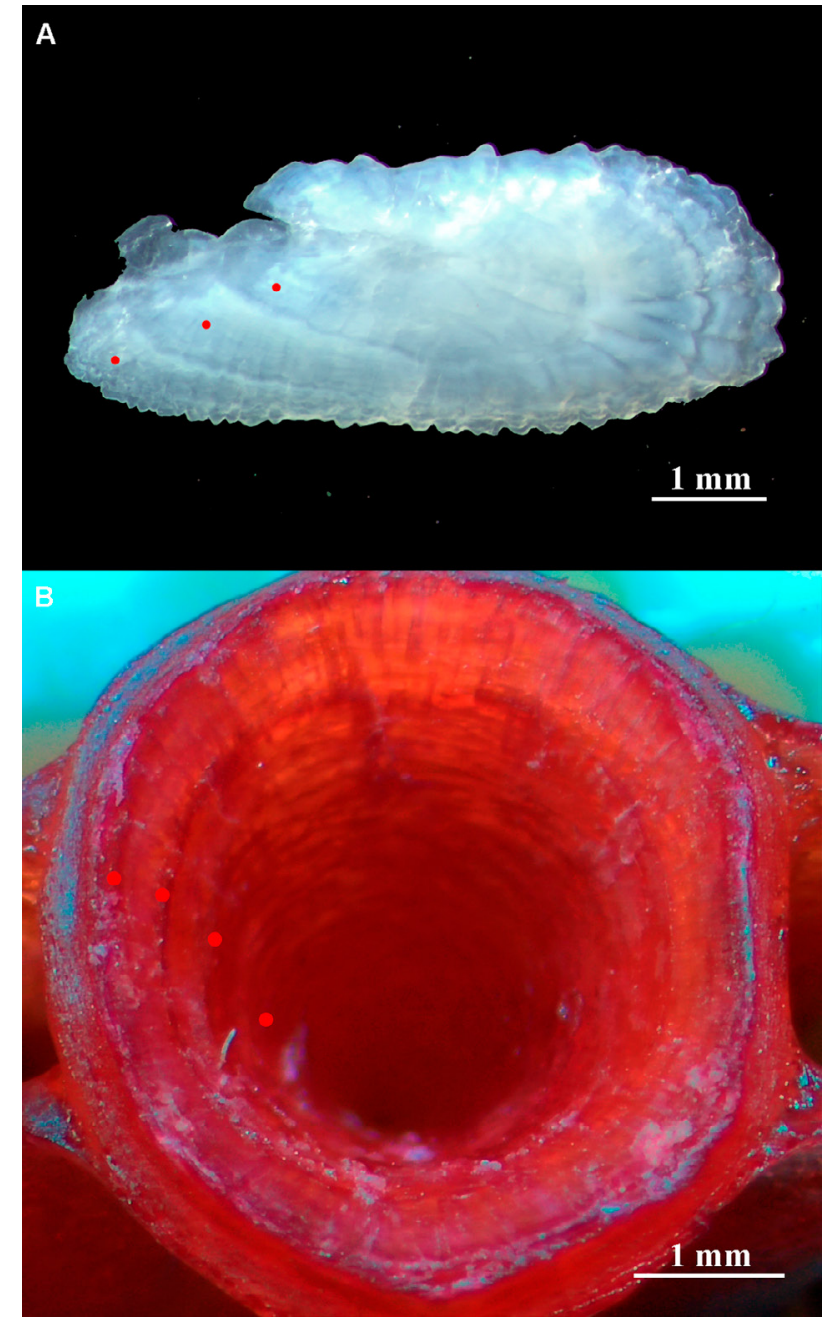

Fig. 2. - Graphical interpretation of annual growth increments in otoliths (A) and the vertebral centrum (B). A, shows an otolith of an individual of Trachinotus ovatus with a length of $24 \mathrm{~cm} L_{\mathrm{F}}$; the otolith has three complete opaque rings, and another one is incomplete at the otolith edge. B, shows a vertebral centrum of an individual of $T$. ovatus with a length of $23.5 \mathrm{~cm} L_{\mathrm{F}}$ and an age of four years.

(Goldman 2005, Battaglia et al. 2016b). We followed the age scheme proposed by Carbonara and Follesa (2019) for fish born on 1 July with a resolution of one year, because this species has its reproduction period between July and October in the Mediterranean Sea (Villegas-Hernández et al. 2016, Assem et al. 2005).

\section{Data analysis}

Length frequency distribution was obtained by plotting the number of observations (individuals) against the size classes of $2 \mathrm{~cm}$. The relationship between $L_{\mathrm{F}}$ and body mass $(M)$ was assessed by linearizing Equation 1 in Table 1 (Le Cren 1951) by means of log-transforming the dependent and independent variables, as suggested by Froese (2006). The linearized equation is also reported in Table 1 (Equation 2). The model's assumptions of normality (standardized residuals vs. theoretical quantiles) and homogeneity (residuals vs. fitted values) were assessed graphically (Fox and Weisberg 2019).
If any of the models obtained violated linear model assumptions, non-linear models were fitted to the data using generalized non-linear least squares (GNLS) estimation and different variance structures (normal distribution, power, exponential and constant plus power of the variance covariate). The GNLS models were constructed in R (lnme package; Pinheiro and Bates 2000, Pinheiro et al. 2019), and the best model was selected according to the lowest Akaike information criterion (AIC) in its small-sample bias-corrected form (AICc) and reported in Equations 6 and 7 in Table 1 (Akaike 1973, Burnham and Anderson, 2002). In addition, residual plots were used to check and validate the selected best model, while Pearson correlation was used to check the relationship between predicted model values and observed values. The values obtained for the $b$ regression coefficients were compared with the theoretical value of isometric growth $(b=3)$ using the Student $t$-test $(\alpha=0.05)$ through the t.test function in the stats package version 3.6.2 (R Core Team 2019). When $b$ is significantly different from 3 ( $p$-value $<0.05$ ), its value indicates allometric growth (negative allometric growth when $b<3$; positive allometric growth when $b>3$; Froese et al. 2011).

To check whether the estimated age was reliable, the precision of age estimation between readers was obtained for each calcified structure (otolith or vertebra) by calculating the following indices using the FSA package in RStudio (Ogle et al. 2019): percentage of agreement (PA; Equation 11 in Table 1); mean coefficient of variation (ACV; Chang 1982; Equation 12 in Table 1); and average percent error (APE; Beamish and Fournier 1981; Equation 13 in Table 1). These data were used to determine which structures (otoliths or vertebrae) are more suitable for estimating the age of the species and then for building the growth model. In further analyses, we considered only the hard structure that showed the highest reliability.

In order to validate the seasonal deposition of translucent and opaque zones (one year in true annuli) and to avoid the inclusion of false rings in the age readings, the otolith edge analysis was performed (Panfili et al. 2002). The monthly percentage of occurrence of opaque rings in the otolith edge was calculated, excluding individuals of age 0 class (Battaglia et al. 2010).

The age-length key (ALK) was created by interpolating age estimation with $L_{\mathrm{F}}$ data organized into size classes of $2 \mathrm{~cm}$ and generating a bubble plot (FSA package version 0.8.24, Ogle et al. 2019). The growth model built using length-at-age data was assessed via the multi-model inference (MMI) approach. The MMI method allowed different growth models to be compared to find the one that best fits with our data (Katsanevakis 2006, Katsanevakis and Maravelias 2008). We selected three length-at-age non-linear least-square regression growth models out of those most used in fishery science (Katsanevakis and Maravelias 2008). These were von Bertalanffy, Gompertz, and logistic models (Equations 3, 4 and 5 in Table 1, respectively; Gompertz 1825, von Bertalanffy 1939, Ricker 1975). Following Ogle (2016), the standard errors were calculated using the bootstrapping method (number of iterations $=999$; nlstools package v. 1.02; Baty et al. 2015). The starting values for the growth parameters $L_{\infty}, K, t_{0}$ (for von Bertalanffy), and I 
Table 1. - List of equations and parameters used in this study. Fork length (LF), body mass (M), natural logarithmic (ln), Akaike information criterion (AIC), small-sample bias-corrected form of AIC (AICc), Delta AIC ( $\Delta$ ), AICc weight (w), growth performance index (GPI), percentage of agreement (PA), mean coefficient of variation (ACV) and average percent error (APE).

\begin{tabular}{|c|c|c|c|}
\hline Equation no. & Definition & Formula & Parameters \\
\hline 1 & $M-L$ & $M_{i}=a L_{i}^{b}$ & \multirow{2}{*}{$\begin{array}{l}M_{\mathrm{i}}=\text { total weight of the fish } \mathrm{i}, \\
L_{\mathrm{i}}=\text { fork length of the fish } \mathrm{i} \\
a=\text { initial growth coefficients } \\
b=\text { fish relative growth rate coefficients }\end{array}$} \\
\hline 2 & $\ln (M)-\ln (L)$ & $\ln \left(M_{i}\right)=\ln (a)+b \ln \left(L_{i}\right)$ & \\
\hline 3 & Von Bertalanffy & $y=L_{\infty}\left(1-e^{\left(-k\left(x-t_{0}\right)\right)}\right)$ & \multirow{3}{*}{$\begin{array}{l}\mathrm{x}=\text { age } \\
\mathrm{y}=\text { expected or mean length at age } \mathrm{x} \\
L_{\infty}=\text { maximum mean length } \\
K=\text { growth rate at which y approaches } L_{\infty} \\
t_{0}=\text { theoretical age or } \mathrm{x} \text {-intercept } \\
\mathrm{I}=\text { age at inflection point }\end{array}$} \\
\hline 4 & Gompertz & $y=L_{\infty} e^{\left(-e^{(-k(x-I))}\right)}$ & \\
\hline 5 & Logistic & $y=L_{\infty}\left(1+e^{(-k(x-I))}\right)^{-1}$ & \\
\hline 6 & $\mathrm{AIC}$ & $A I C=n \log \left(\sigma^{2}\right)+2 K$ & \multirow{2}{*}{$\begin{array}{l}K=\text { total number of parameters }+1 \text { for variance }\left(\sigma^{2}\right) \\
n=\text { sample size }\end{array}$} \\
\hline 7 & $\mathrm{AICc}$ & $A I C_{c}=\left(\frac{2 K(K+1)}{n-K-1}\right)$ & \\
\hline 8 & $\Delta$ & $\Delta_{i}=A I C c_{i}-A I C c_{\min }$ & \multirow{2}{*}{$\begin{array}{l}\Delta=\text { difference between } \mathrm{AICc} \text { of model } \mathrm{i} \text { and lowest } \\
\mathrm{AICc}\left(\mathrm{AICc}_{\min }\right) \\
w=\mathrm{AICc} \text { weight }\end{array}$} \\
\hline 9 & $\mathrm{w}$ & $w_{i}=\frac{\left(e^{\left(-\frac{\Delta_{i}}{2}\right)}\right)}{\left(\sum_{j=1}^{3} e^{\left(-\frac{\Delta_{j}}{2}\right)}\right)}$ & \\
\hline 10 & GPI & $\varphi^{\prime}=2 \log _{10} L_{\infty}+\log _{10} k$ & $\begin{array}{l}k=\text { growth rate at which y approaches } L_{\infty} \\
L_{\infty}=\text { maximum mean length }\end{array}$ \\
\hline 10 & PA & $P A=100 * \frac{C_{r}}{N_{r}}$ & $\begin{array}{l}\mathrm{C}_{\mathrm{r}}=\text { number of coincident readings } \\
\mathrm{N}_{\mathrm{r}}=\text { total number of readings }\end{array}$ \\
\hline \multirow{3}{*}{13} & $\mathrm{ACV}$ & $A C V=100 * \frac{\sum_{j=1}^{n} \frac{s_{j}}{\bar{y}_{j}}}{n}$ & $\begin{array}{l}\mathrm{n}=\text { number of aged fish } \\
\bar{y}_{\mathrm{j}}=\text { mean age for the } \mathrm{jth} \text { fish } \\
\bar{y}_{\mathrm{ij}}=\text { ith age for the } \mathrm{jth} \text { fish } \\
\mathrm{R}=\text { no. of times that each fish was aged } \\
\mathrm{s}_{\mathrm{j}}=\text { standard deviation of } \mathrm{R} \text { age estimates for the } \\
\mathrm{jth} \text { fish }\end{array}$ \\
\hline & \multirow[t]{2}{*}{ APE } & \multirow{2}{*}{$A P E=\frac{\sum_{j=1}^{n} \sum_{i=1}^{K} \frac{\mid \nu, \bar{y}_{j}}{n R}}{n}$} & \multirow[t]{2}{*}{$\begin{array}{l}s_{j}=\text { standard deviation of } \mathrm{R} \text { age estimates for the } \\
\text { jth fish }\end{array}$} \\
\hline & & & \\
\hline 14 & Longevity & $\begin{array}{l}\omega_{L}=T_{\max }\left(1-T_{\max } \cdot E\right) \\
\omega_{U}=T_{\max }(C+E)\end{array}$ & $\begin{array}{l}\omega_{\mathrm{L}}=\text { lower longevity value } \\
\omega_{\mathrm{U}} \text { upper longevity value } \\
\mathrm{T}_{\mathrm{max}=} \text { maximum age detected } \\
\mathrm{E}=\mathrm{APE} \text { calculated from the } 20 \% \text { greatest age as } \\
\text { reference reading } \\
\mathrm{C}=\text { constant equivalent to } 1.4\end{array}$ \\
\hline
\end{tabular}

(for Gompertz) were calculated using the FSA package v.0.8.24 (Ogle 2016). The selection of the best-performing model was based on the AICc (Eqs 6 and 7 in Table 1; Akaike 1973, Burnham and Anderson 2002). AICc is generally preferred over AIC because it performs similarly when the sample size is large (Burnham and Anderson 2002) but is more robust when the sample size is small (Zhu et al. 2009). A further advantage of AICc is that it also provides goodness of fit, measure of complexity and simultaneous comparison of the parameters obtained (Natanson et al. 2014). Finally, delta AICc and AICc weight (Eqs 9 and 10 in Table 1) were calculated using the AICcmodavg package V. 2.2-2 (Mazerolle 2019). The best model was selected based on the lowest AICc value; however, when the $\triangle \mathrm{AICc}$ (difference between the AICc of two models) was $<2$, the model with the highest AICc weight was selected (Akaike 1973, Burnham and Anderson 2002).
The outputs of the growth model analysis allowed the growth performance index to be calculated (Equation 10 in Table 1) following Pauly (1979). Longevity range estimations (upper and lower bounds in equation 14 in Table 1) were calculated following Barnett et al. (2013) and Porcu et al. (2020).

Statistical analysis, models and graphs were constructed using R v. 3.6.2 and RStudio v.1.1.463 (R Core Team 2019, RStudio Team 2015).

\section{RESULTS}

The individuals of $T$. ovatus $(\mathrm{n}=244)$ examined in this study ranged from 2.7 to $30.4 \mathrm{~cm} L_{\mathrm{F}} \quad(\mathrm{n}=244$; mean $=13.2 \pm 1.2 \mathrm{~cm}$ ), and the body mass ranged from 0.3 to $508.6 \mathrm{~g}(\mathrm{n}=244 ;$ mean $=100.6 \pm 15.3 \mathrm{~g})$. The frequency histogram in Figure $3 \mathrm{~A}$ was constructed by plotting the number of specimens grouped into $2 \mathrm{~cm} L_{\mathrm{F}}$ size classes. 


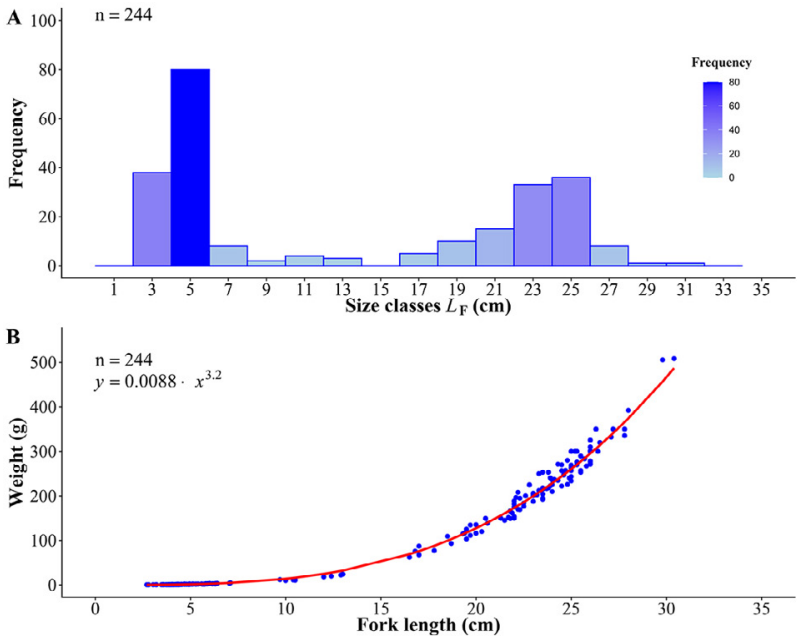

Fig. 3. - Graphic representation of $L$ frequency (A) and non-linear $M-L_{\mathrm{F}}$ length-weight data (B). Sample size (n) and equation are also reported.

Many individuals (80) belonged to the $5 \mathrm{~cm} L_{\mathrm{F}}$ size class, but the size classes of $3 \mathrm{~cm}(\mathrm{n}=38), 25 \mathrm{~cm}(\mathrm{n}=36), 23 \mathrm{~cm}$ $(\mathrm{n}=33)$ and $21 \mathrm{~cm}(\mathrm{n}=15)$ were also quite abundant.

\section{Length-weight relationship}

The length-weight relationship obtained by log-transforming the dependent and independent variables failed to meet the linear regression requirements, so it was necessary to use GNLS with different variance structures. The model with power variance (Table 3 ) was the best-fitting model for the $M-L_{\mathrm{F}}$ data ( 2 in Table 2; $\boldsymbol{\sigma}=0.203$, $a=0.0088 \pm 0.0003, b=3.200 \pm 0.012$ ). It did not show heterogeneity when standardized residuals (residuals divided by the square root of the variance) were plotted against the fitted values. Moreover, high correlation between actual and predicted values was also observed $(\mathrm{r}=0.962, \mathrm{df}=242$, $\mathrm{p}$-value $<0.0001)$. The hypothesis that $T$. ovatus has a positive allometric growth was supported by the results of the relationship between $L_{\mathrm{F}}$ and $M(b=3.200$, lower CI $=3.177$, upper $\mathrm{CI}=3.223, t$-test $=15.061 ; \mathrm{p}<0.001)$.

\section{Precision metrics}

Otoliths and vertebrae from 230 individuals were analysed. The precision of age estimations between

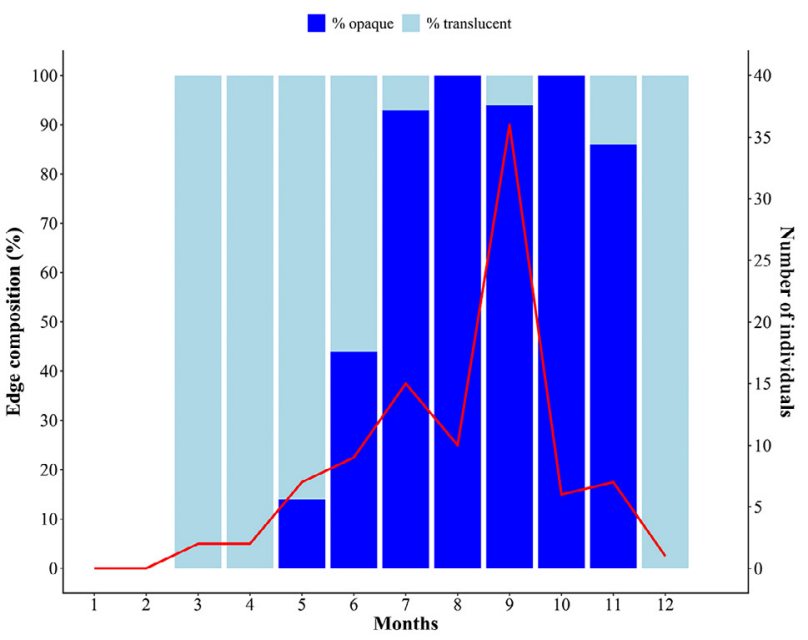

Fig. 4. - Number of individuals (red line) and monthly edge composition (\%) in otoliths of Trachinotus ovatus.

readers showed that readings from otolith structures were more accurate $(97.83 \% \mathrm{PA}, 0.54 \% \mathrm{ACV}$, and $0.38 \%$ APE) than the readings obtained from vertebrae $(82.17 \%$ PA, 5.33\% ACV, and 3.77\% APE). Therefore, the subsequent analysis will use only data generated from the otolith readings of individuals for which both readers estimated the same age $(n=225)$.

\section{Otolith edge analysis}

The otolith edge analysis (Fig. 4) revealed that opaque zones were formed mostly between the summer and autumn seasons, confirming that the deposition of one opaque ring plus one translucent ring corresponds to a period of one year.

\section{Age-length key}

The ALK plot (Fig. 5A) reporting data from the annuli readings in otoliths of $T$. ovatus revealed a total of six age groups (ranging from 0 to 5). Age 0 was the most represented group, with 130 individuals, which ranged between $2.7 \mathrm{~cm}$ and $10.5 \mathrm{~cm} L_{\mathrm{F}}$. Specimens belonging to age 1 group measured more than $9.7 \mathrm{~cm}$ and reached the length of $16.5 \mathrm{~cm} L_{\mathrm{F}}$. The oldest group (age 5) included only four individuals ranging from $26.0 \mathrm{~cm}$ to $30.4 \mathrm{~cm} L_{\mathrm{F}}$ ).

Table 2. - Parameters of the generalized non-linear models $M-L_{\mathrm{f}}(1)$ best variance structure and non-linear growth model (2). Equation number $(\mathrm{N})$, residual standard error $(\sigma)$, degree of freedom $(\mathrm{df})$, coefficient (coef), $95 \%$ confidence interval $(\mathrm{CI}), M\left(\mathrm{y}_{1}\right), L_{\mathrm{F}}\left(x_{1}, y_{2}\right)$, otolith age $\left(x_{2}\right)$, mean growth curve $(\bar{y})$.

\begin{tabular}{cccccccccc}
\hline $\mathrm{N}$ & Type & Models & Equation & $\sigma$ & $\mathrm{df}$ & coef & Estimate & Lower CI & Upper CI \\
\hline \multirow{2}{*}{1} & $\begin{array}{c}\text { Non-linear } \\
\text { model }\end{array}$ & $M-L_{F}$ & $y_{1}=0.009 \cdot x_{1}^{3.200}$ & 0.202 & 242 & $\mathrm{a}$ & 0.009 & 0.008 & 0.009 \\
& & & & & & $\mathrm{~b}$ & 3.200 & 3.177 & 3.223 \\
& Variance & $\sigma^{2}(\overline{\mathrm{y}})^{2 e}$ & $0.041 \cdot(\overline{\mathrm{y}})^{1.682}$ & & & $\mathrm{e}$ & 0.841 & 0.806 & 0.875 \\
& structure & von & $y_{2}=29.139\left(1-e^{\left(-0.496\left(x_{2}+0.347\right)\right)}\right)$ & 1.45 & 222 & $L_{\infty}$ & 29.139 & 27.761 & 30.826 \\
3 & Growth model & Bertalanffy & & & & $k$ & 0.496 & 0.430 & 0.569 \\
& & & & & & $t_{0}$ & -0.347 & -0.393 & -0.309 \\
\hline
\end{tabular}


Table 3. - Variance structure, degree of freedom (df) and small-sample bias-corrected form of the Akaike information criterion (AICc) for each of the four generalized non-linear models constructed using $M$ - $L$ data. The best model was selected considering the lowest AICc. Residual standard error $(\sigma)$ mean growth curve $(\bar{y})$, variance function coefficients (c, d, e and f).

\begin{tabular}{lccc}
\hline Name & Variance structure & df & AICc \\
\hline Normal distribution & $\sigma^{2}(\bar{y})$ & 3 & 1896 \\
Constant plus power & $\sigma^{2}\left(c+\bar{y}^{d}\right)^{2}$ & 5 & 938 \\
Power & $\sigma^{2}(\overline{\mathrm{y}})^{2 e}$ & 4 & 936 \\
Exponential & $\sigma^{2} \exp (\overline{\mathrm{y}})^{2 f}$ & 4 & 1721 \\
\hline
\end{tabular}

\section{Length-at-age growth model}

The comparison of growth models through the MMI method allowed us to identify the von Bertalanffy model $\left(L_{\infty}=29.139 \pm 0.775, k=0.496 \pm 0.036\right.$, and $t_{0}=-0.347 \pm 0.020, \mathrm{df}=222$ and $\sigma=1.45 ; \mathrm{Eq} .4$ in Table 2; Fig. 5b) as the model best fitting to the observed length-at-age data using otolith age estimation. Gompertz and logistic models provided little support based on the AICc selection criterion (Table 4). On the other hand, the von Bertalanffy model showed homogeneity of variance when standardized residuals were observed against fitted values and high correlation between actual and predicted values $(\mathrm{r}=0.988, \mathrm{df}=223$, $\mathrm{p}$-value $<0.0001)$.

Based on the results from the von Bertalanffy growth model, this species is a relatively fast-growing fish, as demonstrated by the growth performance index $\left(\varphi^{\prime}=2.624\right)$. The longevity estimation ranged between five and seven years.

\section{DISCUSSION}

This paper presents a detailed study on the age and growth of T. ovatus. It is the first to use the MMI approach to compare three common growth models in order to understand which best fits the length-at-age data.

The specimens analysed in this study belonged to a wide spectrum of sizes, ranging from small (from 2.7 $\mathrm{cm} L_{\mathrm{F}}$ ) to larger individuals (up to $30.4 \mathrm{~cm} L_{\mathrm{F}}$ ). Morphometric and ponderal measurements and their relationships (e.g. $M-L_{\mathrm{F}}$ ) are important tools in fishery management (Abowei 2009) and stock assessment studies, because they allow either biomass or body length to be estimated when one of these values is lacking. The length-weight relationship is also used to assess the growth performance of cultured fish to determine whether the food intake is transformed into energy for growth (Philipose et al. 2013). In the present study, the analysis of body mass to fork length showed significant positive allometric growth.

In the literature, there are inconsistent data regarding the allometric growth of T. ovatus. As shown in Table 5 , the equation provided by Villegas-Hernández et al. (2016) seems to agree with our study, because their $b$ value was around 3.1 for both sexes in fish ranging between 25 and $44 \mathrm{~cm} L_{\mathrm{T}}$, although these authors did not investigate whether these values were significantly different from the isometric growth value $(b=3)$. On
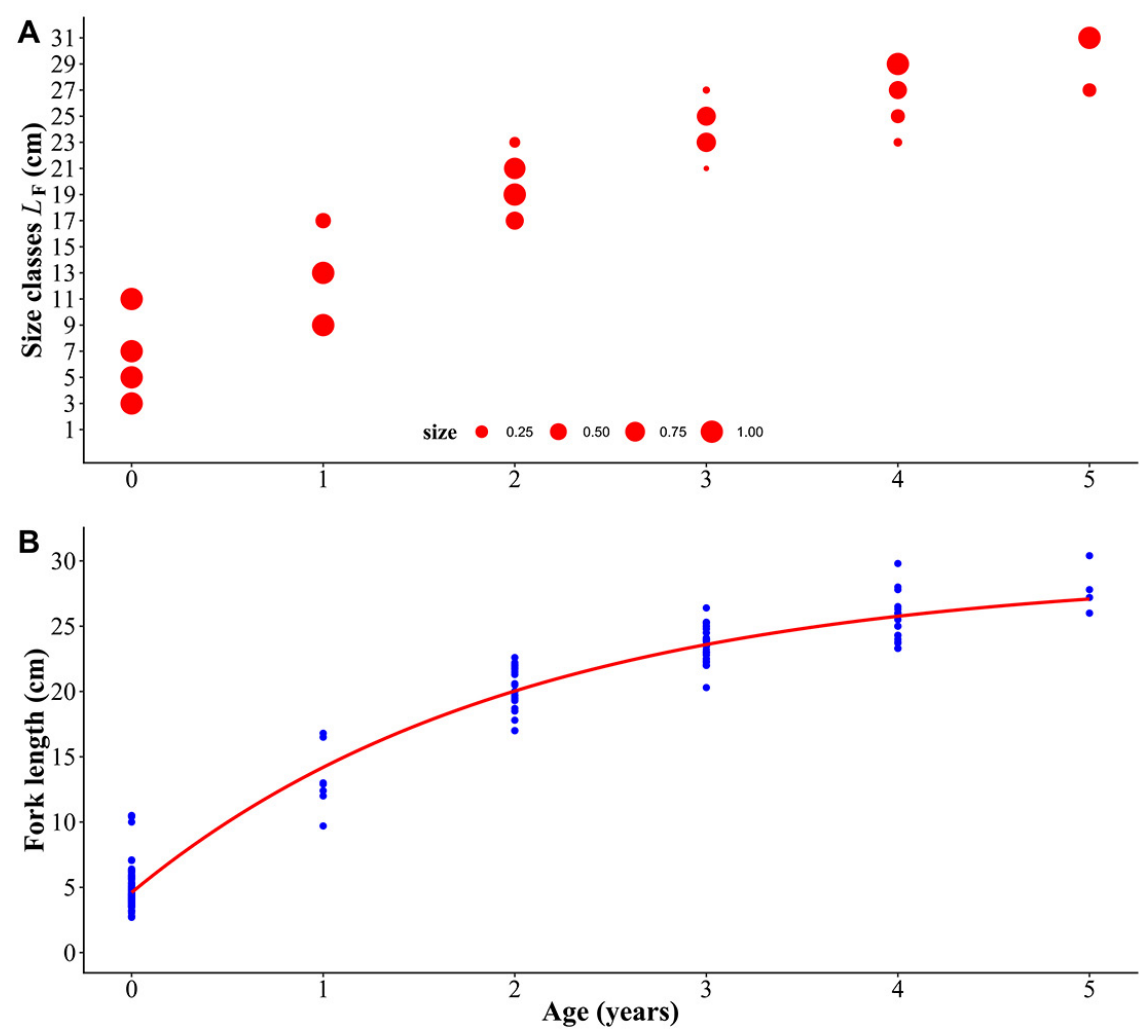

Fig. 5. - Graphical representation of age-length key (A) and von Bertalanffy growth model (B) using age estimated from otolith data ( $\mathrm{n}=225$ ). Bubble plot circles (A) represent the proportions of fish length intervals at a given age. Blue dots (B) in the growth model are the observed ages at a specific length, and the red line is the best-fitting model. 
Table 4. - Ranking of parameters of small-sample bias-corrected form of the Akaike information criterion (AICc) estimated for different growth models based on length-at-age data obtained from otolith readings. The best model was selected considering the lowest AICc and highest AICc weight values.

\begin{tabular}{cccccccc}
\hline Length at age & Model & $\mathrm{k}$ & AICc & Delta AICc & AICc weight & Cumulative weight & Log likelihood \\
\hline Otolith & von Bertalanffy & 4 & 810.93 & 0 & 0.71 & 0.71 & 1 \\
& Gompertz & 4 & 812.70 & 1.77 & 0.29 & -401.37 & -402.26 \\
& Logistic & 4 & 825.16 & 14.23 & 0 & -408.49 \\
\hline
\end{tabular}

Table 5. - Reference list of previous studies reporting $M-L$ relationships of Trachinotus ovatus and comparison with the present paper. Total length $\left(L_{\mathrm{T}}\right)$, fork length $\left(L_{\mathrm{F}}\right)$, initial growth coefficients $(a)$, fish relative growth rate $(b)$, standard errors (se), coefficient of determination $\left(\mathrm{R}^{2}\right)$, isometric (I), allometric negative $\left(\mathrm{A}_{-}^{-}\right)$, allometric positive $\left(\mathrm{A}^{+}\right)$, not assessed (na).

\begin{tabular}{|c|c|c|c|c|c|c|c|c|}
\hline Reference & Gender & $\begin{array}{c}\text { Sample } \\
\text { size }\end{array}$ & $\begin{array}{c}\text { Length } \\
\text { used }\end{array}$ & $\begin{array}{l}\text { Length range } \\
(\mathrm{cm})\end{array}$ & $a \pm \mathrm{se}$ & $b \pm \mathrm{se}$ & $\mathrm{R}^{2}$ & $\begin{array}{c}\text { Growth } \\
\text { type }\end{array}$ \\
\hline Morato et al. (2001) & na & 221 & $L_{\mathrm{T}}$ & $2.6-36.2$ & $0.012^{\dagger}$ & $2.832 \pm 0.021$ & 0.988 & na \\
\hline Abdallah (2002) & na & 45 & $L_{\mathrm{T}}$ & $3.4-23.3$ & $0.022^{\dagger}$ & $2.73^{\dagger}$ & 0.975 & na \\
\hline Santos et al. (2002) & na & 82 & $L_{\mathrm{T}}$ & $29.5-40.5$ & $0.006^{\dagger}$ & $3.096 \pm 0.102$ & 0.919 & I \\
\hline Morey et al. (2003) & na & 99 & $L_{\mathrm{T}}$ & $11.3-34.0$ & $0.008^{\dagger}$ & $2.967 \pm 0.080$ & 0.957 & I \\
\hline Sümer (2012) & na & 26 & $L_{T}$ & $14.1-26.8$ & 0.012 & $2.897 \pm 0.198$ & 0.90 & I \\
\hline Moutopoulos et al. (2013) & na & 12 & $L_{\mathrm{T}}^{T}$ & $22.7-43.2$ & $0.023 \pm 0.554$ & $2.754 \pm 0.377$ & 0.918 & I \\
\hline Oliveira et al. (2015) & na & 33 & $L_{\mathrm{T}}$ & $15.7-44.0$ & $0.009^{\dagger}$ & $2.937 \pm 0.128$ & 0.944 & na \\
\hline Altin et al. (2015) & na & 79 & $L_{\mathrm{T}}$ & $2.9-15.1$ & $0.016 \pm 0.002$ & $2.660 \pm 0.068^{\ddagger}$ & 0.953 & A- \\
\hline \multirow[t]{2}{*}{ Villegas-Hernández et al. $(2016)^{\S}$} & Male & 108 & $L_{T}$ & $25.0-44.0$ & $0.0053^{\dagger}$ & $3.120^{\dagger}$ & 0.919 & na \\
\hline & Female & 118 & $L_{T}$ & $25.0-44.0$ & $0.0043^{\dagger}$ & $3.180^{\dagger}$ & 0.935 & na \\
\hline Reis (2020) & na & 30 & $L_{T}$ & $14.9-26.9$ & $0.0113^{\dagger}$ & $2.901 \pm 0.099 \ddagger$ & 0.971 & A- \\
\hline Present paper & na & 244 & $L_{\mathrm{F}}$ & $2.7-30.4$ & $0.009 \pm 0.0003$ & $3.200 \pm 0.012$ & na & $\mathrm{A}+$ \\
\hline
\end{tabular}

$\uparrow$ Standard errors missing from the original publication.

\$ Standard errors estimated here from the $95 \%$ confidence interval (CI) provided in the original papers, according to the following equation: s.e.=(upper CI - lower CI) / 3.92 .

$\S$ Body mass was calculated as eviscerate weight instead of total weight.

the other hand, Morey et al. (2003) reported isometric growth after analysing 99 individuals ranging from 11.3 to $34.0 \mathrm{~cm} L_{\mathrm{T}}$ from the western Mediterranean Sea and the Balearic Islands. Similarly, Santos et al. (2002), Sümer (2012), and Moutopoulos et al. (2013) also found isometric growth using total length $\left(L_{\mathrm{T}}\right)$ measurements, respectively, from 82 individuals obtained from the Atlantic Portuguese coast (size range 29.5$40.5 \mathrm{~cm}$ ); from 26 individuals from the southwestern coast of Turkey (size range 14.1-26.8); and from 12 individuals from Greek waters (size range 22.7-43.2 $\mathrm{cm})$. Moreover, although Oliveira et al. (2015) did not mention this, their $b$ value calculated based on 33 individuals of T. ovatus from the tropical northeastern Atlantic seems to indicate isometric growth. Negative allometric growth for this species was observed by Altin et al. (2015) and Reis (2020), who analysed samples from the Aegean Sea, as well as in studies conducted in captivity (Tutman et al. 2004, Guo et al. 2014, Zhang et al. 2016). Although it is not mentioned in their papers, it seems that Morato et al. (2001) and Abdallah M. (2002) also obtained negative allometric growth after examining individuals of T. ovatus from the northeastern Atlantic and Mediterranean Egyptian waters, respectively (Table 5).

This discrepancy in results may be explained by differences in the samples sizes and fish length ranges, as well as by growth variations between the sexes (Le Cren 1951, Froese 2006). However, although most papers did not specifically assess the $M-L$ relationship for sexes, according to Villegas-Hernández et al. (2016), the length-weight relationship of T. ovatus seems not to display any differences between males and females. Other possible causes of these differences may be inter-regional (within the Mediterranean Sea) or regional (between the Mediterranean Sea and other areas; Sparre et al. 1989) variations in fish populations, possibly caused by differences in water temperature or food availability-factors that usually affect the fish growth (Jobling 1997, Mommsen 1998). It is plausible that the sea temperature may influence the growth of a thermophilic species such as $T$. ovatus. The recent increase in sea water temperature due to climate change (Nykjaer 2009; Shaltout and Omstedt 2014) certainly affects the biology, ecology abundance, and distribution of species characterized by a warm thermal affinity (Lasram et al. 2010; Albouy et al. 2013; Givan et al. 2018). Within the Mediterranean Sea, T. ovatus has been observed moving to the northeast (Azzurro 2008, Azzurro et al. 2011), extending its geographical distribution towards other Mediterranean areas where it has not been previously observed (Tunçer et al. 2020).

Given the recent interest in this species by some artisanal fisheries (e.g. Battaglia et al. 2017a), fishing pressure may influence the stocks and their life history traits to some extent, also creating some differences in growth between exploited and unexploited populations from different areas.

The analysis of the age estimations of T. ovatus allowed us to observe that the species can reach the age of five years and a length of up to $30.4 \mathrm{~cm} L_{\mathrm{F}}$. The age estimated in the present paper is higher than the 
maximum age provided by Mourad (1999), who observed individuals that were over three years old and up to about $25 \mathrm{~cm} L_{\mathrm{T}}$ after analysing $T$. ovatus from the Mediterranean Egyptian coast (i.e. the fish were smaller than the ones we collected).

A range of hard structures have been used for fish age estimation in the literature, including scales, vertebrae, otoliths, cleithra, fin rays, urohyal bone, and opercular bones (Das 1994). However, not all are equally reliable (Bostanci et al. 2009), causing differences in estimation of several population parameters (Campana 2001). Moreover, it is not always possible to examine the preferred structures. Hence, comparative studies of age estimation based on different hard structures are useful for determining whether readings provide similar results (Moltschaniwskyj and Cappo 2009). Campana (2001) suggested that a cut-off of 5\% ACV where values greater than $5 \%$ should be considered imprecise. In the present paper, otolith readings seem to yield more accurate age estimates than vertebra readings, with the ACV greater than 5\%; for this reason, following Campana's suggestion, vertebrae were not analysed further. The otolith edge analysis confirmed the yearly deposition of growth increments (one opaque and one translucent ring), which is also observed in other carangids (Carbonara and Follesa 2019). The best growth function, selected based on the MMI approach using otolith readings, was the von Bertalanffy one. The growth performance index $\left(\varphi^{\prime}\right)$ was 2.624 , and longevity was estimated between $5\left(\omega_{L}\right)$ and $7\left(\omega_{U}\right)$ years. To our knowledge, these parameters have never been assessed for a wild population of T. ovatus from the Mediterranean Sea, so it is impossible to compare our growth rate estimates and model with other data. As mentioned above, we can only compare our rough age data with data reported by Mourad (1999), which assumed a maximum age of three years based on individuals of $T$. ovatus between 8 and $26 \mathrm{~cm} L_{\mathrm{T}}$. These data agree with our age readings, although we investigated a larger size spectrum, resulting in a maximum age of five years observed in a few individuals. Nevertheless, some authors have investigated other species belonging to the genus Trachinotus from eastern Australia (T. botla; McPhee 1999), the Gulf of Mexico (T. carolinus; Muller et al. 2002, Murphy et al. 2007), and South Africa (T. botla; Parker and Booth 2015). We can compare our results to theirs. In our study, the age data fitted well with the von Bertalanffy growth model, whereas Parker and Booth (2015) observed an almost linear age-length relationship in T. botla. Moreover, our estimation of $L_{\infty}(29.139$ $\left.\mathrm{cm} L_{F}\right)$ showed that $T$. ovatus can reach a fork length below that of $T$. carolinus $\left(39.9 L_{F}\right.$, Muller et al. 2002; $33.7 \mathrm{~cm} L_{F}$, Murphy et al. 2007).

The present data help extend the current knowledge on T. ovatus and can be used as a baseline for the management of this species in the Mediterranean region. $T$. ovatus is considered a fishery resource, having commercial value in several Mediterranean fisheries (Azzurro et al. 2011, Battaglia et al. 2017a). Length-at-age data and parameters of growth models for fish species are useful for stock assessment and aquaculture.

\section{REFERENCES}

Abdallah M. 2002. Length-weight relationship of fishes caught by trawl off Alexandria, Egypt. Naga, The ICLARM Quart. 25: $19-20$.

Abowei J.F.N. 2009. The morphology, abundance, condition factor and length-weight relationship of Ethmalosa fimbriata (Bowdish 1825) from Nkoro river Niger Delta, Nigeria. Adv. J. Food. Sci. Technol. 1: 51-56.

Akaike H. 1973. Information theory and an extension of the maximum likelihood principle. In: Petrov B. N., Csaki F. (eds), Second international symposium on information theory, pp. 267-281.

Albouy C., Guilhaumon F., Leprieur F., et al. 2013. Projected climate change and the changing biogeography of coastal Mediterranean fishes. J. Biogeogr. 40: 534-547. https://doi.org/10.1111/jbi.12013

Altin A., Ayyildiz H., Kale S., et al. 2015. Length-weight relationships of forty-nine fish species from shallow waters of Gökceada Island, northern Aegean Sea Turkey. Turk. Zool. 39: 971-975. https://doi.org/10.3906/zoo-1412-15

Andaloro F., Rinaldi A. 1998. Fish biodiversity change in Mediterranean Sea as tropicalisation phenomenon indicator. In: Enne G., D'Angelo M., Zanolla C. (eds), Indicators for Assessing Desertification in the Mediterranean. ANPA, Rome, pp. 201-206.

Assem S.S., El-Serafy S.S., El-Garabawy M.M., et al. 2005. Some biochemical aspects of reproduction in female Trachinotus ovatus (Carangidae). Egypt. J. Aquat. Res. 31: 315-327.

Azzurro E. 2008. The advance of thermophilic fishes in the Mediterranean Sea: overview and methodological questions. In: Briand F. (ed), Mediterranean Marine Biota. CIESM workshop monographs, Monaco, pp. 39-45.

Azzurro E., Moschella P., Maynou F. 2011. Tracking signals of change in Mediterranean fish diversity based on local ecological knowledge. PLoS ONE 6: e24885. https://doi.org/10.1371/journal.pone.0024885

Batistić M., Tutman P., Bojanić D., et al. 2005. Diet and diel feeding activity of juvenile pompano (Trachinotus ovatus) (Teleostei: Carangidae) from the southern Adriatic, Croatia. J. Mar. Biolog. Assoc. U.K. 85: 1533-1534. https://doi.org/10.1017/S0025315405012749

Battaglia P., Castriota L., Consoli P., et al. 2010. Age and growth of pearly razorfish, Xyrichtys novacula (Linnaeus 1758), in the central Mediterranean Sea. J. Appl. Ichthyol. 26: 410-415. https://doi.org/10.1111/j.1439-0426.2009.01383.x

Battaglia P., Pedà C., Musolino S., et al. 2016a. Diet and first documented data on plastic ingestion of Trachinotus ovatus L. 1758 (Pisces: Carangidae) from the Strait of Messina (central Mediterranean Sea). Ital. J. Zool. 83: 121-129. https://doi.org/10.1080/11250003.2015.1114157

Battaglia P., Potoschi A., Valastro M., et al. 2016b. Age, growth, biological and ecological aspects of Remora osteochir (Echeneidae) in the Mediterranean Sea. J. Mar. Biol. Assoc. UK 96: 639-645. https://doi.org/10.1017/S0025315415000867

Battaglia P., Andaloro F., Consoli P., et al. 2017a. Baseline data to characterize and manage the small-scale fishery (SSF) of an oncoming Marine Protected Area (Cape Milazzo, Italy) in the western Mediterranean Sea. Ocean Coast Manage. 148: 231-244. https://doi.org/10.1016/i.ocecoaman.2017.08.014

Battaglia P., Ammendolia G., Cavallaro M., et al. 2017b. Influence of lunar phases, winds and seasonality on the stranding of mesopelagic fish in the Strait of Messina (Central Mediterranean Sea). Mar. Ecol. 38: e12459. https://doi.org/10.1111/maec.12459

Baty F., Ritz C., Charles S., et al. 2015. A Toolbox for Nonlinear Regression in R: The Package nlstools. J. Stat. Softw. 66: 1-21. https://doi.org/10.18637/jss.v066.i05

Beamish R.J., Fournier D.A. 1981. A method for comparing the precision of a set of age determinations. Can. J. Fish. Aquat. Sci. 38: 982-983. https://doi.org/10.1139/f81-132

Barnett L.A.K., Winton M.V., Ainsley S.M., et al. 2013. Comparative demography of skates: Life-history correlates of productivity and implications for management. PLoS ONE 8: e65000. https://doi.org/10.1371/journal.pone.0065000 
Bianchi C.N., Corsini-Foka M., Morri C., et al. 2014. Thirty years after - dramatic change in the coastal marine habitats of Kos Island (Greece), 1981-2013. Med. Mar. Sci. 15: 482-497. https://doi.org/10.12681/mms.678

Bostanci D., Polat N., Yilmaz S. 2009. Age determination and annulus formation of crucian carp (Carassius gibelio) inhabiting Egirdir lake and Bafra fish lake, Turkey. J. Freshw. Ecol. 24: 331-333. https://doi.org/10.1080/02705060.2009.9664300

Burnham K.P., Anderson D.R. 2002. Model selection and multimodel inference: A practical information-theoretic approach. Springer-Verlag, New York, pp. 487.

Campana S.E. 2001. Accuracy, precision and quality control in age determination, including a review of the use and abuse of age validation methods. J. Fish. Biol. 59: 197-242. https://doi.org/10.1111/j.1095-8649.2001.tb00127.x

Carbonara P., Follesa M.C. 2019. Handbook on fish age determination: a Mediterranean experience. Studies and Reviews. FAO, Roma, pp. 1-192

Castriota L., Falautano M., Battaglia P., et al. 2014. New biological data on Fistularia commersonii in the central Mediterranean Sea. Cybium 38: 15-21.

Chang W.Y.B. 1982. A statistical method for evaluating the reproducibility of age determination. Can. J. Fish. Aquat. Sci. 39: $1208-1210$ https://doi.org/10.1139/f82-158

Chervinski J., Zorn M. 1977. Note on occurrence and the food of juvenile kachlan (Trachinotus ovatus, Linnaeus) (Pisces, Carangidae) from the Mediterranean. Aquaculture 10: 179-185. https://doi.org/10.1016/0044-8486(77)90020-5

Consoli P., Battaglia P., Castriota L., et al. 2010. Age, growth and feeding habits of the bluemouth rockfish, Helicolenus dactylopterus dactylopterus (Delaroche 1809) in the central Mediterranean (southern Tyrrhenian Sea). J. Appl. Ichthyol. 26: 583-591. https://doi.org/10.1111/j.1439-0426.2010.01467.x

Das M. 1994. Age determination and longevity in fishes. Gerontology 40: 70-96. https://doi.org/10.1159/000213580

Froese R. 2006. Cube law, condition factor and weight-length relationships: history, meta-analysis and recommendations. J. Appl. Ichthyol. 22: 241-253. https://doi.org/10.1111/j.1439-0426.2006.00805.x

Froese R., Tsikliras A.C., Stergiou, K.I. 2011. Editorial note on weight-length relations of fishes. Acta Ichthyol. Piscat. 41: 261-263. https://doi.org/10.3750/AIP2011.41.4.01

Fox J., Weisberg S. 2019. An R Companion to Applied Regression (Third). SAGE Publications Inc, pp. 608.

Givan O., Edelist D., Sonin O., et al. 2018. Thermal affinity as the dominant factor changing Mediterranean fish abundances. Global Change Biol. 24: e80-e89. https://doi.org/10.1111/gcb.13835

Goldman K.J. 2005. Age and growth of Elasmobranch fishes. In: Musick J. A., Bonfil R. (eds), Management tecniques for Elasmobranch fisheries. FAO Fish. Tech. Pap. No. 474. Rome, pp. 76-102

Gompertz B. 1825. XXIV. On the nature of the function expressive of the law of human mortality, and on a new mode of determining the value of life contingencies. In a letter to Francis Baily, Esq. F.R.S. \& c., Philos. Trans. R. Soc. 115: 513-583. https://doi.org/10.1098/rstl.1825.0026

Guo H., Ma Z., Jiang S., et al. 2014. Length-weight relationship of oval pompano, Trachinotus ovatus (Linnaeus 1758) (Pisces: Carangidae) cultured in open sea floating sea cages in South China Sea. Indian J. Fish. 61: 93-95.

Jobling M. 1997. Temperature and growth: Modulation of growth rate via temperature change. In: Wood C.M. Mcdonald D.G. (eds), Global Warming: Implications for freshwater and marine fish. Cambridge Univ. Press, Cambridge, pp. $225-254$. https://doi.org/10.1017/CBO9780511983375.010

Katsanevakis S. 2006. Modelling fish growth: Model selection, multi-model inference and model selection uncertainty. Fish. Res. 81: 229-235. https://doi.org/10.1016/j.fishres.2006.07.002

Katsanevakis S., Maravelias C.D. 2008. Modelling fish growth: multi-model inference as a better alternative to a priori using von Bertalanffy equation. Fish Fish. 9: 178-187. https://doi.org/10.1111/j.1467-2979.2008.00279.x
Lasram F.B.R., Guilhaumon F., Albouy C., et al. 2010. The Mediterranean Sea as a 'cul-de-sac' for endemic fishes facing climate change. Global Change Biol. 16: 3233-3245. https://doi.org/10.1111/j.1365-2486.2010.02224.x

Le Cren E.D. 1951. The length-weight relationship and seasonal cycle in gonad weight and condition in the perch (Perca fluviatilis). J. Anim. Ecol. 20: 201-219. https://doi.org/10.2307/1540

Lejeusne C., Chevaldonne P., Pergent-Martini C., et al. 2010. Climate change effects on a miniature ocean: the highly diverse, highly impacted Mediterranean Sea. Trends Ecol. Evol. 25: 250-260. https://doi.org/10.1016/j.tree.2009.10.009

Liu S., Wang S., Cai Y., et al. 2020. Beneficial effects of a host gut-derived probiotic, Bacillus pumilus, on the growth, non-specific immune response and disease resistance of juvenile golden pompano, Trachinotus ovatus. Aquaculture 514: 734446. https://doi.org/10.1016/j.aquaculture.2019.734446

Liu B., Guo H.Y., Zhu K.C., et al. 2019. Growth, physiological, and molecular responses of golden pompano Trachinotus ovatus (Linnaeus, 1758) reared at different salinities. Fish Physiol. Biochem. 45: 1879-1893. https://doi.org/10.1007/s10695-019-00684-9

Mazerolle M. J. 2019. AICcmodavg: Model selection and multimodel inference based on (Q)AIC(c). R package version 2.2-2.

McPhee D.P. 1999. The biology and management of the surf zone carangid Trachinotus botla in Queensland, Australia. $\mathrm{PhD}$ thesis, Univ. Queen, $226 \mathrm{pp}$.

Moltschaniwskyj N., Cappo M. 2009. Alternatives to sectioned otoliths: The use of other structures and chemical techniques to estimate age and growth for marine vertebrates and invertebrates. In: Green B.S., Mapstone B.D., et al. (eds), Tropical fish otoliths: Information for assessment, management and ecology. Springer Netherlands, Dordrecht, pp. 133-173. https://doi.org/10.1007/978-1-4020-5775-5 5

Mommsen T. P. 1998. Growth and metabolism. In: Evans D.H. (eds), The physiology of fishes. CRC Press, New York, pp. 65-97.

Morato T., Afonso P., Lourinho P., et al. 2001. Length-weight relationships for 21 coastal fish species of the Azores, north-eastern Atlantic. Fish. Res. 50: 297-302. https://doi.org/10.1016/S0165-7836(00)00215-0

Morey G., Moranta J., Massuti E., et al. 2003. Weight-length relationships of littoral to lower slope fishes from the western Mediterranean. Fish. Res. 62: 89-96. https://doi.org/10.1016/S0165-7836(02)00250-3

Mourad M.H. 1999. Age determination of Trachinotus ovatus (L.) based on otolith weight. J. KAU: Mar. Sci. 10: 149-155. https://doi.org/10.4197/mar.10-1.10

Moutopoulos D.K., Ramfos A., Mouka A., et al. 2013. Lengthweight relations of 34 fish species caught by small-scale fishery in Korinthiakos Gulf (Central Greece). Acta Ichthyol. Piscat. 43: 57-64. https://doi.org/10.3750/AIP2013.43.1.08

Muller R.G., Tisdel K., Murphy M.D. 2002. The 2002 update of the stock assessment of Florida pompano (Trachinotus carolinus). Florida Mar. Res. Instit., Florida, St. Petersburg, $43 \mathrm{pp}$.

Munday P.L. Jones G.P., Pratchett M.S., et al. 2008. Climate change and the future for coral reef fishes. Fish Fish. 9: 261-285. https://doi.org/10.1111/j.1467-2979.2008.00281.x

Murphy M.D., Muller R.G., Guindon K. 2007. A stock assessment for pompano, Trachinotus carolinus, in Florida waters through 2005. FWRI In House Report. Fish and Wildlife Res. Instit., Florida, St. Petersburg, 113 pp.

Natanson L.J., Adams D.H., Winton M.V., et al. 2014. Age and growth of the bull shark in the western north Atlantic ocean. Trans. Am. Fish. Soc. 143: 732-743. https://doi.org/10.1080/00028487.2014.892537

Nykjaer L. 2009. Mediterranean Sea surface warming 19852006. Clim. Res. 39: 11-17. https://doi.org/10.3354/cr00794

Ogle D. 2016. Introductory Fisheries Analyses with R. In: Chambers J.M., Lang D.T., et al. (eds), Chapman \& Hall/CRC, The R Series. CRC Press, Florida, Boca Raton, 317 pp. https://doi.org/10.1201/b19232

Ogle D. H., Wheeler P., Dinno A. 2019. FSA: Fisheries Stock Analysis. R package version 0.8.23. 
Oliveira M.T., Santos M.N., Coelho R., et al. 2015. Weight-length and length-length relationships for reef fish species from the Cape Verde Archipelago (tropical north-eastern Atlantic). J. Appl. Ichthyol. 31: 236-241. https://doi.org/10.1111/jai.12497

Panfili J., Troadec H., Pontual H.D., et al. 2002. Manual of fish sclerochronology. Ifremer-IRD coedition, France, Brest, 464 pp.

Pankhurst N.W., Munday P.L. 2011. Effects of climate change on fish reproduction and early life history stages. Mar. Freshw. Res. 62: 1015-1026.

Parker D., Booth A. J. 2015. Aspects of the biology and life history of largespot pompano, Trachinotus botla, in South Africa. Mar. Freshw. Res. 66: 247-255. https://doi.org/10.1071/MF14029

Pauly D. 1979. Gill size and temperature as governing factors in fish growth: a generalization of von Bertalanffy's growth formula. Chris.-Albrec. Univ. Kiel. 63: 1-156.

Pinheiro J., Bates D. 2000. Mixed-effects models in S and S-PLUS. Statistics and computing. Springer, New York, 528 pp. https://doi.org/10.1007/978-1-4419-0318-1

Pinheiro J., Bates D., DebRoy S., et al. 2019. nlme: Linear and Nonlinear Mixed Effects Models. R package version 3.1-143.

Philipose K.K., Divu D., Krupesha S.S.R., et al. 2013. Lengthweight relationship of Asian seabass, Lates calcarifer (Bloch) reared in open sea floating cages. Indian J. Fish. 60: 139-140.

Porcu C., Bellodi A., Cau A., et al. 2020. Uncommon biological patterns of a little known endemic Mediterranean skate, Raja polystigma (Risso, 1810). Reg. Stud. Mar. Sci. 34: 101065. https://doi.org/10.1016/j.rsma.2020.101065

Pranovi F., Anelli Monti M., Brigolin D., et al. 2016. The influence of the spatial scale on the fishery landings-SST relationship. Front. Mar. Sci. 3: 143. https://doi.org/10.3389/fmars.2016.00143

R Core Team. 2019. R: A language and environment for statistical computing. R Foundation for Statistical Computing.

Reiner F. 1996. Catálogo dos peixes do Arquipélago de Cabo Verde. Instituto Português de Investigacão Marítima, Lisboa, $339 \mathrm{pp}$.

Reis İ. 2020. Length-weight relationships of 12 fish species from the Köyceğiz Lagoon, Turkey. Mar. Sci. Tech. Bull. 9: 136144. https://doi.org/10.33714/masteb.722480

Ricker W.E. 1975. Computation and interpretation of biological statistics of fish populations. J. Fish. Res. Board. Can. 191: $1-382$.

RStudio Team 2015. RStudio: integrated development for R. RStudio Inc., version 0.99.896.

Santos M.N., Gaspar M.B., Vasconcelos P., et al. 2002. Weightlength relationships for 50 selected fish species of the Algarve coast (southern Portugal). Fish. Res. 59: 289-295. https://doi.org/10.1016/S0165-7836(01)00401-5

Shaltout M., Omstedt A. 2014. Recent sea surface temperature trends and future scenarios for the Mediterranean Sea. Oceanologia 56: 411-443.

https://doi.org/10.5697/oc.56-3.411
Smith-Vaniz W. 1986. The Carangidae. In Whitehead P., Bauchot M. L., et al. (eds). Fishes of the North-Eastern Atlantic and the Mediterranean. UNESCO, Paris, pp. 815-844. https://doi.org/10.2307/1444931

Sparre P., Ursin E., Venema S. 1989. Introduction to tropical fish stock assessment. Part 1. Manual. FAO Fish. Tech. Pap., Rome, 429 pp.

Sümer Ç. 2012. Length-weight relationships of 15 lagoon fish species collected in the Beymelek Lagoon (SW Turkey). Cah. Biol. Mar. 53: 185-188.

Tan X., Lin H., Huang Z., et al. 2016. Effects of dietary leucine on growth performance, feed utilization, non-specific immune responses and gut morphology of juvenile golden pompano Trachinotus ovatus. Aquaculture 465: 100-107. https://doi.org/10.1016/j. aquaculture.2016.08.034

Tan X., Sun Z., Huang Z., et al. 2017. Effects of dietary hawthorn extract on growth performance, immune responses, growth-and immune-related genes expression of juvenile golden pompano (Trachinotus ovatus) and its susceptibility to Vibrio harveyi infection. Fish shellfish Immunol. 70: 656-664. https://doi.org/10.1016/j.fsi.2017.09.041

Tortonese E. 1975. Fauna d'Italia, XI. Osteichthyes, parte II. Edizioni Calderini, Bologna, 636 pp.

Tunçer S., Koç H., Erdoğan Z. 2020. Occurrence of the golden pompano, Trachinotus ovatus (Linnaeus 1758) (Osteichtyes: Carangidae) in Dardanelles, the Sea of Marmara. Nat. Eng. Sci. 5: 37-44. https://doi.org/10.28978/nesciences.691695

Tutman P., Glavić N., Kožul V., et al. 2004. Preliminary information on feeding and growth of pompano, Trachinotus ovatus (Linnaeus, 1758) (Pisces; Carangidae) in captivity. Aquac. Int. 12: 387-393. https://doi.org/10.1023/B:AQUI.0000042135.88381.f4

Villegas-Hernández H., Muñoz M., Lloret J. 2016. Reproductive traits of the pompano, Trachinotus ovatus (Linnaeus, 1758), in the north-western Mediterranean. J. Mar. Biol. Assoc. UK 96: 1053-1063. https://doi.org/10.1017/S0025315415001265

Von Bertalanffy L. 1939. A quantitative theory of organic growth (inquiries on growth laws ii). Human Biol. 10: 181213.

Yang Q., Ma Z. 2016. Effect of temperature on growth, survival and occurrence of skeletal deformity in the golden pompano Trachinotus ovatus larvae. Indian J. Fish. 63: 74-82. https://doi.org/10.21077/ijf.2016.63.1.51490-10

Zhang N., Yang Q., Ma Z., et al. 2016. Length-Weight relationship, condition factor, gonads index, and visceral mass index of golden pompano (Trachinotus ovatus) (Pisces: Carangidae) from South China Sea. Int. J. Innov. Stud. Aqu. Biol. Fish. 2: 39-42 https://doi.org/10.20431/2455-7670.0202004

Zhu L., Li L., Liang Z. 2009. Comparison of six statistical approaches in the selection of appropriate fish growth models. Chin. J. Oceanol. Limnol. 27: 457. https://doi.org/10.1007/s00343-009-9236-6 